\title{
FAKTOR-FAKTOR YANG MEMPENGARUHI KEBIJAKAN CASH HOLDING PADA PERUSAHAAN MANUFAKTUR YANG TERDAFTAR DI BURSA EFEK INDONESIA
}

\author{
KRISTINA NOPIANTI NAINGGOLAN \\ AFNI ELIANA SARAGIH
}

Program Studi Akuntansi Universitas Katolik Santo Thomas Medan

kristinanopianti22@gmail.com; afni.elianasaragih@gmail.com

\begin{abstract}
ABSTRAK
Penelitian ini bertujuan untuk mengetahui pengaruh profitability, leverage, cash conversion cycle dan net working capital terhadap cash holding pada perusahaan manufaktur yang terdaftar di Bursa Efek Indonesia tahun 2014-2017. Teknik pengambilan sampel yang digunakan adalah purposive sampling dengan jumlah sampel sebanyak 15 perusahaan. Data diperoleh dari Bursa Efek Indonesia tahun 2014-2017. Teknik analisis data yang digunakan adalah Regresi Linier Berganda dengan tingkat signifikansi sebesar 5\% setelah melewati Uji Asumsi klasik yaitu uji normalitas data, uji multikolonieritas, uji autokorelasi, dan uji heteroskedastisitas. Hasil uji secara parsial menunjukkan bahwa profitability dannet working capital berpengaruh Positif secara signifikan terhadap cash holding, sedangkan leveragedan cash conversion cycleberpengaruh negatif tidak signifikan terhadap cash holding. Hasil uji secara simultan menunjukkan bahwa profitability, leverage, cash conversion cycle dan net working capital berpengaruh terhadap cash holding. Kemampuan variabel independen dalam menjelaskan variabel dependen sebesar $22,6 \%$ sedangkan sisanya sebesar $77,4 \%$ dijelaskan oleh variabel lain di luar model penelitian ini.
\end{abstract}

Kata kunci : Cash Holding, Profitability, Leverage, Cash Conversion Cycle dan Net Working Capital

\section{PENDAHULUAN}

Cash holding merupakan salah satu aset likuid yang berbentuk sejumlah uang kartal yang dimiliki oleh perusahaan yang disimpan di dalam kas kecil (petty cash), atau dalam kas register, atau dalam bentuk rekening-rekening baik itu di dalam bank maupun didalam pasar uang. Cash holding bertujuan untuk menjaga ketersediaan kas bagi perusahaan dalam menjalankan operasional usaha, terutama dalam membiayai kegiatan operasional perusahaan. Memiliki jumlah kas yang optimal dapat memberikan berbagai macam keuntungan bagi perusahaan, seperti keuntungan dari potongan dagang (trade discount), terjaganya posisi perusahaan dalam peringkat kredit (credit rating), dan untuk membiayai kebutuhan yang tidak terduga (unexpected expenses) (Marfuah dan 
Zulhilmi, 2014). Dengan keuntungan seperti itu, perusahaan dapat lebih aman dalam menjalankan operasional perusahaan apabila memiliki ketersediaan kas yang cukup.

Namun menyimpan kas terlalu banyak juga bukanlah hal yang efektif.Menyimpan kas terlalu banyak dapat menyebakan hilangnya kesempatan untuk mendapat keuntungan dibandingkan jika kas diinvestasikan. Selain itu kas yang dipegang juga dapat berkurang karena pengenaan pajak atau risiko kehilangan (Marfuah dan Zulhilmi, 2014). Dengan berbagai macam keuntungan dan kerugian dari cash holding, permasalahan yang dihadapkan oleh manajer pada perusahaan saat ini adalah apakah manajer akan menahan kas untuk berjaga-jaga, atau melakukan investasi guna mendapatkan keuntungan bagi perusahaan. Oleh karena itu, seorang manajer harus memiliki kemampuan mengelola jumlah kas yang liquid. Dengan semakin pentingnya mengatur jumlah kas yang ideal bagi perusahaan, telah menumbuhkan perhatian dari berbagai kalangan baik para ekskutif, analis, dan investor terhadap cash holding.

Kebijakan cash holding suatu perusahaan dengan perusahaan lain berbeda satu sama lain. Hal ini diakibatkan adanya perbedaan karakteristik dan kondisi yang dihadapi oleh perusahaan dan juga motivasi yang berbeda dalam memegang kas. Literatur ekonomi dan keuangan telah mengidentifikasi 3 hal yang umumnya menjadi motif perusahaan dalam memegang kas yang dikemukakan oleh John Maynard Keynes dalam Ross (2015:208), yaitu kebutuhan untuk transaksi, kebutuhan untuk berjagajaga, dan kebutuhan untuk spekulasi.

Kebijakancash holding dapat dijelaskan menggunakan tiga teori yaitu, Trade-off Theory (Modigliani dan Miller, 1963), Agency Theory (Jensen dan Meckling, 1976) dan Pecking Order Theory (Myers dan Majluf, 1984). Pertama, Trade-off Theory menyatakan bahwa terdapat dua konsep dalam penahanan kas, yaitu biaya memegang kas dan manfaat yang didapatkan dari memegang kas dalam jumlah yang optimal. Kedua, Agency Theory menghubungkan tingkat kas di suatu perusahaan dengan bagian menajerial, di mana manajer pada perusahaan dengan peluang investasi rendah cenderung menahan kas daripada membayarkannya pada pemegang saham. Ketiga, Pecking Order Theory menjelaskan bahwa pembiayaan pada dasarnya berasal dari tiga sumber, yang pertama berasal dari laba ditahan. Apabila pendanaan internal ini tidak mencukupi untuk mendanai kegiatan investasi perusahaan maka akan dilanjutkan ke alternatif kedua yaitu menggunakan utang. Ketika jumlah utang yang dimiliki dirasa sudah 
berlebihan, pendanaan investasi dilanjutkan ke pilihan alternatif terakhir dengan mengeluarkan ekuitas (Hanafi dan Halim, 2014).

Penelitian ini menganalisis faktor-faktor yang mempengaruhi cash holding, diantaranya profitability, leverage, cash conversion cycle dan net working capital. Menurut Gitman dan Zulter (2015) dalam Simanjuntak dan Wahyuni (2017) mendefenisikan profitabilitymerupakan hubungan antara pendapatan dan biaya yang dihasilkan dari penggunakan aset perusahaan baik aset lancar maupun aset tetap.

Tabel 1 Data Profitability dan Cash Holding di BEI

\begin{tabular}{|c|c|c|c|c|c|}
\hline No & $\begin{array}{l}\text { Kode } \\
\text { Emiten }\end{array}$ & Nama Perusahaan & Tahun & Profitability & $\begin{array}{l}\text { Cash } \\
\text { Holding }\end{array}$ \\
\hline \multirow{2}{*}{1} & \multirow{2}{*}{ CEKA } & \multirow{2}{*}{$\begin{array}{l}\text { PT. Cahaya Kalbar } \\
\text { Tbk }\end{array}$} & 2014 & 0,032 & 0,022 \\
\hline & & & 2015 & 0,072 & 0,007 \\
\hline \multirow{2}{*}{2} & \multirow{2}{*}{ DLTA } & \multirow{2}{*}{$\begin{array}{l}\text { PT. Delta Djakarta } \\
\text { Tbk }\end{array}$} & 2014 & 0,289 & 0,418 \\
\hline & & & 2015 & 0,185 & 0,478 \\
\hline \multirow[b]{2}{*}{3} & \multirow{2}{*}{ INDF } & \multirow{2}{*}{$\begin{array}{l}\text { PT. Indofood Sukses } \\
\text { Makmur Tbk }\end{array}$} & 2014 & 0,102 & 0,172 \\
\hline & & & 2015 & 0,111 & 0,154 \\
\hline
\end{tabular}

Sumber : Data diolah dari www.idx.co.id

DariTabel 1 dapat dilihat nilai profitabilityPT Cahaya Kalbar Tbk dan PT Indofood Sukses makmur pada tahun 2014-2015 meningkat dari 0,032 menjadi 0,072, dan dari 0,102 menjadi 0,111 sedangkan cash holding perusahaan yang sama tahun 2014-2015 menurun dari 0,022 menjadi 0,007 dan dari 0,172 menjadi 154. Kemudian nilai profitabilityPT Delta Djakarta Tbk tahun 2014-2015 menurun dari 0,289 menjadi 0,185 sedangkan nilai cash holdingperusahaan tersebut mengalami kenaikan dari 0,418 menjadi 0,478 .

Hal tersebut berbeda dengan hasil penelitian terdahulu Gitman dan Zulter (2015) dalam Simanjuntak dan Wahyuni (2017) bahwa variabel profitabilityadalah hasil antara kebijakan dan keputusan yang diambil oleh perusahaan serta hubungan antara pendapatan dan biaya yang dihasilkan perusahaan dengan menggunakan aset perusahaan dalam melaksanakan aktivitas produksi. Yang berarti Semakin besar kemampuan perusahaan dalam menghasilkan laba, maka semakin besar pula jumlah kas perusahaan yang dimiliki. 
Menurut Ali et al. (2016) dalam Simanjuntak dan Wahyuni (2017) menyatakan bahwa leveragemerupakan kondisi dimana perusahaan membeli asetnya secara kredit dengan kepercayaan bahwa laba dari aset tersebut akan lebih jika dibandingkan melakukan pinjaman.

Tabel 2 Data Leverage dan Cash Holding di BEI

\begin{tabular}{|l|l|l|c|c|c|}
\hline No & $\begin{array}{l}\text { Kode } \\
\text { Emiten }\end{array}$ & Nama Perusahaan & Tahun & Leverage & $\begin{array}{l}\text { Cash } \\
\text { Holding }\end{array}$ \\
\hline 1 & AISA & $\begin{array}{l}\text { PT. Tiga Pilar } \\
\text { Sejahtera Food Tbk }\end{array}$ & 2014 & 0,514 & 0,165 \\
\cline { 3 - 6 } 2 & CEKA & PT. Cahaya kalbar Tbk & 2015 & 0,560 & 0,065 \\
\cline { 3 - 6 } 3 & ULTJ & $\begin{array}{l}\text { PT. Ultrajaya Milik } \\
\text { Industry and Trading }\end{array}$ & 2015 & 0,342 & 0,022 \\
\cline { 3 - 6 } & & 2014 & 0,569 & 0,007 \\
\hline
\end{tabular}

Sumber : Data diolah dari www.idx.co.id

Tabel di atas menunjukkan data PT. Tiga Pilar Sejahtera Tbk dan PT Cahaya Kalbar dari tahun 2014 ke tahun 2015 mengalami peningkatan nilai leveragedari 0,514 menjadi 0,560 dan dari 0,342 menjadi 0,569 sedangkan nilai cash holding mengalami penurunan dari 0,165 menjadi 0,065 dan dari 0,022 menjadi 0,007. Kemudian PT. Ultrajaya Milik Industry and Trading Company Tbk dari tahun 2014-2015 mengalami penurunan nilai leveragedari 0,221 menjadi 0,209 dan nilai cash holding mengalami kenaikan dari 0,168 menjadi 0,240.

Hal tersebut berbeda dengan peneliti terdahulu Gitman dan Zutter (2015) dalamSimanjuntak dan Wahyuni (2017)menyatakan bahwaleveragemengukur proporsi total aset yang dimiliki perusahaan yang dibiayai oleh hutang. Semakin besar rasio leveragemaka semakin besar pula uang pihak eksternal yang digunakan untuk menghasilkan laba. Semakin besar tingkat leverageperusahaan menunjukkan tingkat pinjaman yang besar pula, yang berarti uang kas perusahaan akan bertambah.

Menurut Syarief dan Wilujeng (2009) dalam William dan Fauzi (2013) cash conversion cycle (siklus konversi kas) didefenisikan sebagai waktu dalam satuan hari yang diperlukan untuk mendapatkan kas dari hasil operasi perusahaan yang berasal dari penagihan piutang ditambah penjualan persediaan dikurangi dengan pembayaran utang. Siklus konversi 
kas menunjukkan seberapa cepat perusahaan menghasilkan produknya, dari membayar biaya persediaan hingga mengumpulkan kas dari konsumen dalam bentuk pembayaran atas produk jadi. Semakin lamasiklus initerjadi, semakin besar kebutuhan pendanaan internal perusahaan untuk membayar kebutuhan bahan baku perusahaan.

Tabel 3 Data Cash Conversion Cycle dan Cash Holding di BEI

\begin{tabular}{|l|l|l|c|c|c|}
\hline \multirow{2}{*}{ No } & $\begin{array}{l}\text { Kode } \\
\text { Emiten }\end{array}$ & Nama Perusahaan & Tahun & $\begin{array}{l}\text { Cash } \\
\text { Conversion } \\
\text { Cycle }\end{array}$ & $\begin{array}{l}\text { Cash } \\
\text { Holding }\end{array}$ \\
\hline \multirow{2}{*}{1} & SKLT & PT. Sekar Laut Tbk & 2014 & 48,676 & 0,022 \\
\cline { 4 - 6 } 2 & \multirow{2}{*}{ PSDN } & $\begin{array}{l}\text { PT. Prashida Aneka } \\
\text { Niaga Tbk }\end{array}$ & 2015 & 49,914 & 0,020 \\
\cline { 4 - 6 } 3 & \multirow{2}{*}{ SKBM } & PT. Sekar Bumi Tbk & 2014 & 94,010 & 0,055 \\
\cline { 4 - 6 } & & 2015 & 94,741 & 0,045 \\
\hline
\end{tabular}

Sumber : Data diolah dari www.idx.co.id

Tabel 3 di atas menunjukkan data PT. Sekar Laut Tbk dari tahun 2014 ke tahun 2015 yang mengalami kenaikan nilai cash conversion cycle(siklus konversi kas semakin lama) dari 48,676 menjadi 49,914 namun nilai cash holding mengalami penurunan dari 0,022 menjadi 0,020. Kemudian PT. Sekar Bumi Tbk dari tahun 2014-2015 mengalami penurunan nilai cash conversion cycledari 37,030 menjadi 37,090 dan nilai cash holding mengalami kenaikan dari 0,192 menjadi 0,141.

Hal tersebut berbeda dengan peneliti terdahulu Bigelli dan Vidal dalam William dan Fauzi (2013) menyatakan bahwa jika perusahaan dapat mengelola siklus konversi kas mereka menjadi lebih singkat, maka mereka akan membutuhkan saldo kas dalam jumlah yang lebih kecil dibandingkan dengan perusahaan yang memiliki siklus konversi kas yang panjang. Dengan demikian, perusahaan yang memiliki siklus konversi kas yang singkat akan memegang kas dalam jumlah sedikit. Sebaliknya perusahaan yang memiliki siklus konversi kas yang panjang akan memegang kas dalam jumlah yang banyak.

Menurut Ross et al. (2015) dalam Simanjuntak dan Wahyuni (2017)Net Working Capital merupakan aset lancar dan kewajiban lancar yang dapat menghasilkan modal kerja yang positif saat aset lancar lebih besar dari kewajiban lancar. Gitman dan Zutter (2015) menyatakan bahwa 
Net Working Capitaladalah selisih antara aset lancar perusahaan dengan kewajiban lancar perusahaan. Jika modal kerja perusahaan semakin besar maka jumlah kas yang dimiliki juga besar karena jumlah aset yang dimiliki melebihi hutang yang dimiliki perusahaan. Apabila modal kerja terlalu besar maka, dana yang tertanam dalam modal kerja melebihi kebutuhan, sehingga terjadi dana menganggur, tetapi apabila jumlah modal kerja terlalu sedikit atau kecil, maka perusahaan akan kurang mampu memenuhi permintaan konsumen. Secara umum perusahaan harus mampu mempertahankan jumlah modal kerja yang menguntungkan yaitu jumlah aktiva lancar harus lebih besar dari pada jumlah hutang lancarnya, sehingga perusahaan menjadi likuid yaitu mampu membayar hutangnya yang telah jatuh tempo. Semakin besar selisih antara aktiva lancar dan hutang lancar maka semakin efisien penggunaan modal kerja, maka semakin kecil risiko yang harus ditanggung perusahaan dan semakin tinggi kemampuan perusahaan dalam meningkatkan profitabilitas.

Tabel 4 Data Net Working Capital dan Cash Holding di BEI

\begin{tabular}{|l|l|l|c|c|c|}
\hline No & $\begin{array}{l}\text { Kode } \\
\text { Emiten }\end{array}$ & Nama Perusahaan & Tahun & $\begin{array}{l}\text { Net } \\
\text { Working } \\
\text { Capital }\end{array}$ & $\begin{array}{l}\text { Cash } \\
\text { Holding }\end{array}$ \\
\hline 1 & \multirow{2}{*}{ STTP } & PT. Siantar Top Tbk & 2014 & $-0,062$ & 0,015 \\
\cline { 3 - 6 } 2 & \multirow{2}{*}{ MLBI } & $\begin{array}{l}\text { PT. Multi Bintang } \\
\text { Indonesia Tbk }\end{array}$ & 2015 & $-0,018$ & 0,009 \\
\cline { 3 - 6 } 3 & CEKA & $\begin{array}{l}\text { PT. Cahaya kalbar } \\
\text { Tbk }\end{array}$ & 2015 & $-0,386$ & 0,066 \\
\cline { 3 - 6 } & & 2015 & 0,454 & 0,164 \\
\hline
\end{tabular}

Sumber : Data diolah dari www.idx.co.id

Tabel di atas menunjukkan data PT Siantar Top dan PT. Cahaya Kalbar Tbk dari tahun 2014 ke tahun 2015 mengalami peningkatan nilai net working capital dari -0,062 menjadi -0,018 dan dari 0,239 menjadi 0,274, sedangkan nilai cash holding mengalami penurunan dari 0,015 menjadi 0,009 dan dari 0,022 menjadi 0,007. Kemudian PT. Multi Bintang Indonesia Tbk dari tahun 2014-2015 mengalami penurunan nilai net working capitaldari $-0,386$ menjadi $-0,454$ dan nilai cash holding mengalami kenaikan dari 0,066 menjadi 0,164.

Hal tersebut berbeda dengan teori yang menyatakan net working capital dianggap berpengaruh terhadap cash holding karena menurut teori 
financial constrains and subtitutes, net working capital memiliki hubungan terbalik atau negatif terhadap cash holding. Maksudnya adalah apabila perusahaan memiliki net working capital yang tinggi maka saldo kas yangdimiliki akan sedikit. Hal ini dikarenakan kemampuan net working capitalyang dapat berubah menjadi kas sewaktu-waktu. Teori tersebut sesuai dengan penelitian yang dilakukan oleh William dan Fauzi (2013), dalam penelitiannya perusahaan sektor tambang yang terdaftar di BEI memiliki net working capitalyang mempengaruhi cash holding, sehingga dapat disimpulkan bahwa net working capital dapat menjadi pengganti bagi kas.

Penelitian ini bermaksud untuk menganalisis faktor-faktor yang mempengaruhi cash holding pada perusahaan sektor pertambangan yang terdaftar di Bursa Efek Indonesia tahun 2014-2017. Perbedaan penelitian ini dengan penelitian terdahulu terdapat pada objek penelitian.Penelitian ini dilakukan pada perusahaan manufaktur yang terdaftar di Bursa Efek Indonesia periode 2014-2017.Selain objek penelitian, peneliti juga menambahkan dua variabel baru yaitu profitability dan leverage.

\section{TINJAUAN PUSTAKA DAN PENGEMBANGAN HIPOTESIS}

\section{Cash Holding}

Berdasarkan PSAK No. 2 tahun 2009, kas terdiri dari saldo kas (cash on hand) dan rekening giro (demand deposits).Sedangkan setara kas adalah investasi yang sifatnya sangat likuid, berjangka pendek dan yang dengan cepat dijadikan kas dalam jumlah yang ditentukan.MenurutTerueletal(2009) dalam Wijaya et.al.(2010), cash holding merupakan rasio yang membandingkan antara jumlah kas dan setara kas yang dimiliki perusahaan dengan jumlah aktiva perusahaan secara keseluruhan. Kas merupakan bentuk aktiva yang paling likuid, karena sifatnya yang likuid tersebut, membuat kas memiliki tingkat keuntungan yang paling rendah dibandingkan apabila kas tersebut diinvestasikan dalam bentuk aset lain yang lebih menguntungkan, seperti misalnya deposito berjangka, membeli obligasi perusahaan lain, dan sebagainya. Oleh karena itu, ketersediaan jumlah kas yang optimal bagi perusahaan dapat mempengaruhi keuntungan yang didapatkan oleh perusahaan tersebut.

Jumlah kas yang terlalu banyak, akan berdampak pada kerugian perusahaan atas setiap peluang investasi yang terlewatkan. Namun apabila jumlah terlalu sedikit juga akan berpengaruh pada likuiditas untuk kebutuhan operasional perusahaan.Dengan tersedianya kas dalam jumlah 
yang cukup, perusahaan tidak harus mengorbankan kesempatan investasi yang dimilikinya untuk mempertahankan likuiditasnya. Menurut Brigham dan Houston (2006), perusahaan manufaktur rata-rata memiliki jumlah kas sebesar $1,5 \%$ dari total aktiva.Pengelolaan terhadap jumlah kas perusahaan menjadi suatu perhatian khusus bagi perusahaan mengingat menentukan jumlah kas yang tepat untuk kegiatan operasional perusahaan bukanlah perkara yang mudah.

Menurut John Maynard Keynes,dalam karya klasiknya The General Theory of Employment, Interest, and Money mengidentifikasikan tiga motif perusahaanmenahan kas, antaralain:

a) Transactionmotive (motif transaksi),menurut teori ini perusahaan menahan kas untuk membiayai berbagai transaksi perusahaan. Apabila perusahaan mudah mendapatkan dana dari pasar modal, cash holding tidak diperlukan. Namun, jika perusahaan tidak dapat dengan mudah mendapatkan dana dari pasar modal maka perusahaan perlu cash holding untuk membiayaiberbagai transaksi. Selain itu, apabila terdapat asimetri informasi dan agencycostof debt yang tinggi akan menjadikan sumber pendanaan eksternal juga akan semakin tinggi dan menyebabkan jumlah cash holding juga menjadi semakin besar.

b) Precautionmotive (motif berjaga-jaga), menurut teori ini perusahaan menahan kas dengan tujuan untuk mengantisipasi peristiwa yang tidakterduga dariaspekpembiayaan,terutamapada negara dengankondisiperekonomian yangtidakstabil.Pasarmodal akan terpengaruh oleh keadaan ekonomiyang bersifatmakro sepertinilaitukar matauangyang dapatberpengaruh terhadap nilaihutang perusahaan.Hal ini menyebabkan perusahaan menahan kas dalam jumlah besar untuk mengantisipasiberbagai kemungkinan buruk dariperekonomian.

c) Speculation motive (motif spekulasi), teori ini menyatakan bahwa perusahaan akan menggunakan kasuntuk berspekulasi mengamati berbagai kesempatan bisnis baru yang dianggap menguntungkan. Misalnyaperusahaanyang sedang berkembang dapatmelakukan akuisisi perusahaan sehinggamemerlukankasdalam jumlah besar.

\section{Profitability}

Menurut Kasmir (2011:114) menyatakan bahwa profitability merupakan rasio untuk menilai kemampuan perusahaan dalam mencari keuntungan atau laba dalam suatu periode tertentu. Rasio ini juga 
memberikan ukuran tingkat efektifitas manajemen suatu perusahaan yang ditunjukkan dari laba yang dihasilkan dari penjualan atau dari pendapatan investasi. Dikatakan suatu perusahaan rentabilitasnya baik apabila mampu memenuhi target laba yang telah ditetapkan dengan menggunakan aktiva atau modal yang dimilikinya.

Profitabilitas merupakan tingkat keuntungan bersih yang diperoleh perusahaan dalam menjalankan operasinya (Utami dan Prasetiono,2016). Dalam penelitian ini kemampuan laba diwakili oleh Return on Assets(ROA) yang merupakan rasio untuk mengukur efektivitas perusahaan di dalam menghasilkan keuntungan dengan memanfaatkan total aktiva yang dimiliki oleh perusahaan.

\section{Leverage}

MenurutFahmi (2014:75) leverage merupakan ukuran seberapa besar perusahaan dibiayai dengan hutang. Leverage merupakan rasio keuangan perusahaan yang membandingkan antara total utang dengan total aset perusahaan (Marfuah dan Zulhilmi, 2015). Penggunaan hutang yang terlalu tinggi akan membahayakan perusahaan karena perusahaan akan masuk dalam kategori extremeleverage (hutang ekstrim) yaitu perusahaan terjebak dalam tingkat hutang yang tinggi dan sulit untuk melepaskan beban hutang tersebut. Karena itu sebaiknya perusahaan harus menyeimbangkan berapa banyak hutang yang layak diambil dan dari mana sumber-sumber yang dapat dipakai untuk membayar hutang.

\section{Cash Conversion Cycle}

Menurut Lukas Setia Atmaja dalam Fahmi (2014:136), cash conversion cycle(siklus konversi kas) adalah waktu rata-rata antara penjualan untuk sumber daya produktif dengan penerimaan kas dari penjualan produk. Menurut Syariefdan Wilujeng (2009)cash conversion cycle didefenisikan sebagai waktu dalam satuan hari yang diperlukan untuk mendapatkan kas dari hasil operasi perusahaan yang berasal dari penagihan piutang ditambah penjualan persediaan dikurangi dengan pembayaran utang.

Siklus konversi kas menunjukkan seberapa cepat perusahaan menghasilkan produknya, dari membayar biaya persediaan hingga mengumpulkan kas dari konsumen dalam bentuk pembayaran atas produk jadi. Semakin lama siklus ini terjadi, semakin besar kebutuhan pendanaan internal perusahaan untuk membayar kebutuhan bahan baku perusahaan. 
Menurut Opler et al.(1999)dalamWilliam dan Fauzi(2013), perusahaan dengan beberapa lini produk dan perusahaan dengan persediaan barang yang siap dijual rendah memiliki siklus konversi kas pendek akan memegang aset lancar dalam jumlah yang lebih sedikit. Lebih lanjut, Bigelli dan Vidal (2009) dalam William dan Fauzi (2013), mengatakan bahwa jika perusahaan dapat mengelola siklus konversi kas mereka menjadi lebih singkat, maka mereka akan membutuhkan saldo kas dalam jumlah yang lebih kecil dibandingkan dengan perusahaan yang memiliki siklus konversi kas yang panjang.

\section{Net Working Capital}

Menurut Kasmir (2011:251) net working capitalmerupakan seluruh komponen aktiva lancar dikurangi dengan total kewajiban lancar (utang jangka pendek). Menurut Ross et al. (2015) dalamSimanjuntak dan Wahyuni (2017) menyatakan bahwa net working capital merupakan aset lancar dan kewajiban lancar yang dapat menghasilkan modal kerja yang positif saat aset lancar lebih besar dari kewajiban lancar. Gitman dan Zutter (2015) menyatakan bahwa net working capitaladalah selisih antara aset lancar perusahaan dengan kewajiban lancar perusahaan. Jika modal kerja perusahaan semakin besar maka jumlah kas yang dimiliki juga besar karena jumlah aset yang dimiliki melebihi hutang yang dimiliki perusahaan.

Menurut teori financial constrains and subtitutes, net working capitalmemiliki hubungan terbalik atau negatif terhadap cash holding. Maksudnya adalah apabila perusahaan memiliki net working capitalyang tinggi maka saldo kas perusahaan akan sedikit. Hal ini dikarenakan kemampuan net working capitalyang dapat berubah menjadi kas sewaktuwaktu. Teori tersebut sesuai dengan penelitian yang dilakukanoleh William dan Fauzi (2013), dalam penelitiannya pada perusahaan sektor tambang yang terdaftar di BEI menemukannet working capitalberpengaruh terhadapcash holding. Dapat disimpulkan bahwa net working capital dapat menjadi pengganti bagi kas.

\section{Pengaruh Profitability Terhadap Cash Holding}

Gitman dan Zutter (2015) mendefenisikan profitability sebagaihubungan antara pendapatan dengan biaya yang dihasilkan dari penggunaan aset perusahaan baik aset lancar maupun aset tetap. Berdasarkan defenisi diatas dapat disimpulkan bahwa profitability adalah hasil kebijakan dan keputusan yang diambil oleh perusahaan serta 
hubungan antara pendapatan dan biaya yang dihasilkan perusahaan dengan menggunakan aset perusahaan dalam melaksanakan aktivitas produksi.

Profitability merupakan kemampuan perusahaan menghasilkan laba dalam periode tertentu. Profitabilitas yang tinggi menunjukkan kemampuan perusahaan menghasilkan keuntungan yang tinggi bagi perusahaan. Keuntungan akan menjadi laba ditahan yang digunakan sebagai penyangga bagi perusahaan dan dapat menambah cash holding. Hal ini sesuai dengan pecking order theory yang menyatakan bahwa perusahaan lebih memilih menggunakan laba ditahan sebagai tambahan modal dibandingkan mendapatkannya melalui penerbitan ekuitas yang tergolong mahal. Yeboah dan Agyei dalam Silaen (2017) menjelaskan bahwa perusahaan dengan tingkat profitability yang tinggi akan menyebabkan perusahaan memegang jumlah kas yang besar pula. Yang artinya semakin besar kemampuan perusahaan dalam menghasilkan laba, maka semakin besar pula jumlah kas perusahaan yang dimiliki.

$\mathrm{H}_{1} \quad$ : Profitability berpengaruh positif terhadap cash holding

\section{Pengaruh Leverage terhadap Cash Holding}

Ali et al.(2015) dalam Simanjuntak dan Wahyuni (2017) menyatakan bahwa leverage merupakan kondisi dimana perusahaan membeli asetnya secara kredit dengan kepercayaan bahwa laba dari aset tersebut akan lebih jika dibandingkan melakukan pinjaman. Gitman dan Zutter dalam Simanjuntak dan Wahyuni (2017) menyatakan bahwa leverage mengukur proporsi total aset yang dimiliki perusahaan yang dibiayai oleh hutang. Semakin besar rasio leverage maka semakin besar pula uang pihak eksternal yang digunakan untuk menghasilkan laba. Semakin besar tingkat leverage perusahaan menunjukan tingkat pinjaman yang besar pula, yang berarti uang kas perusahaan akan bertambah.

Berdasarkan trade-off theory, perusahaan dengan leverage yang tinggi akan berusaha untuk meminimalkan biaya kas dengan pendanaan eksternal. Leverage yang tinggi menunjukkan kemampuan rasio perusahaan untuk menerbitkan hutang sehingga perusahaan dapat menggunakan pinjaman sebagai pengganti cash holding. Ferreira dan Vilela (2004) menemukan bahwa perusahaan dengan tingkat leverage yang lebih tinggi memiliki kemampuan untuk mendapatkan pendanaan eksternal lebih mudah dan murah sehingga memungkinkan perusahaan untuk mengurangi jumlah kas yang dipegang. Penelitian yang dilakukan oleh William dan Fauzi (2004) juga menemukan bahwa perusahaan dengan rasio utang yang lebih tinggi memiliki posisi kas yang lebih rendah.

$\mathrm{H}_{2}$ : Leverage berpengaruh negatif terhadap cash holding 


\section{Pengaruh Cash Conversion Cycleterhadap Cash Holding}

Siklus konversi kas menunjukkanseberapa cepat perusahaan menghasilkan produknya, dari membayar biaya persediaan hingga mengumpulkan kas dari konsumen dalam bentuk pembayaran atas produk jadi. Semakin lama siklus ini terjadi, semakin besar kebutuhan pendanaan internal perusahaan untuk membayar kebutuhan bahan baku perusahaan.

Cash conversion cycleatau siklus konversi kas adalah waktu yang dibutuhkan perusahaan mulai dari saat perusahaan mengeluarkan uang untuk membeli bahan bakusampai dengan perusahaan mengumpulkan uang dari penjualan barang jadi. Secara teori, semakin pendek waktu yang diperlukan, semakin baik bagi perusahaan, sebaliknya, semakin panjang waktu yang diperlukan, semakin banyak modal yang harus ditanamkan.

William dan Fauzi (2013) menyatakan bahwa perusahaan baik sektor publik maupun swasta tidak begitu memerlukan kas jika mereka memiliki siklus konverensi kas yang singkat. Hubungan antara cash conversion cycledan cash holding lebih jelas ditunjukkan oleh penelitian yang dilakukan oleh Bigelli dan Vidal (2012) dalam William dan Fauzi (2013) yakni perusahaan yang memiliki siklus konversi kas yang cukup lama akan memegang kas dalam jumlah yang besar.

$\mathrm{H}_{3}$ : Cash conversion cycle berpengaruh positif terhadap cash holding

\section{Pengaruh Net Working Capital terhadap Cash Holding}

Net Working Capitalmampu berperan sebagai substitusi terhadap cash holding perusahaan. Hal ini dikarenakan kemudahan dalam mengubahnya kedalam bentuk kas saat perusahaan memerlukannya. Net Working Capital diukur dengan membagi pengurangan current assets dan current liabilities dengan total assets. Apabila hasil net working capital negatif atau yang biasa disebut defisit modal kerja, maka perusahaan disinyalir tengah mengalami kesulitan likuiditas. Pada umumnya, perusahaan dengannet working capital negatif akanmembuat cadangan kas. Sebaliknya jika perusahaan memiliki net working capital yang besar otomatis akan mengurangi kas saldo mereka. Argumen ini telah dibuktikan oleh penelitian Afza dan Adnan (2007) maupun Meggison dan Wei (2010). $\mathrm{H}_{4}$ :Net Working Capital berpengaruh negatif terhadap cash holding

\section{METODE PENELITIAN}

\section{Populasi dan Sampel}

Populasi penelitian ini adalah perusahaan manufaktur yang terdaftar di Bursa Efek Indonesia tahun 2014-2017. Sampel penelitian dipilih 
dengan menggunakan pendekatan purposive sampling. Sampel dipilih berdasarkan kriteria, maksud dan tujuan tertentu dan diperoleh sebanyak 15 perusahaan sebagai sampel penelitian. Kriteria yang digunakan antara lain:

a. Perusahaan termasuk kategori perusahaan manufaktur kelompok Makanan dan Minuman.

b. Perusahaan menerbitkan laporan keuangan 31 Desember yang telah diaudit tahun 2014-2017

\section{Defenisi Operasional Variabel}

\section{a. Cash Holding}

Cash holding. Rasio yang membandingkan antara jumlah kas dan setarakas yang dimiliki perusahaan dengan jumlah aktiva perusahaan secara keseluruhan (Marfuah dan Zulhilmi,2015). Ukuran yang digunakan untuk menghitung nilai cash holding adalah sebagai berikut :

$$
\text { Cash Holding }=\frac{\text { Kas+Setara Kas }}{\text { Total Aset }}
$$

\section{b. Profitability $\left(\mathrm{X}_{1}\right)$}

Dalam penelitian ini kemampuan laba diwakili oleh Return on Assets(ROA) yang merupakan rasio untuk mengukur efektivitas perusahaan di dalam menghasilkan keuntungan dengan memanfaatkan total aktiva yang dimiliki oleh perusahaan. Menurut Webston dan Copeland (1996) ROA merupakan perbandingan antara laba operasi bersih terhadap total aktiva. ROA diformulasikan sebagai berikut:

$$
\text { Return On Asset }=\frac{\text { Net Income }}{\text { Total Assets }} \times 100 \%
$$

\section{c. Leverage $\left(\mathrm{X}_{2}\right)$}

Leverage merupakan rasio yang digunakan untuk mengukur sejauhmana aktiva perusahaan dibiayai dengan utang. Leverage merupakan rasio keuangan perusahaan yang membandingkan antara total utang dengan total aset perusahaan (Marfuah dan Zulhilmi, 2015). Leverage dapat dihitung dengan rumus sebagai berikut:

$$
\text { Leverage }=\frac{\text { Total Liabilities }}{\text { Total Assets }}
$$

d. Cash Conversion Cycle $\left(\mathrm{X}_{3}\right)$

Cash conversion cycle didefenisikan sebagai waktu dalam satuan hari yang diperlukan untuk mendapatkan kas dari hasil operasi perusahaan yang 
berasal dari penagihan piutang ditambah penjualan persediaan dikurangi dengan pembayaran utang (Syarief dan Wilujeng (2009). adalah:

Ukuran yang digunakan untuk menghitung cash conversion cycle

Cash Conversion Cylce $=$ Days Inventory + Days Receivable -

Days Payable

- Days Inventory $=\frac{365}{\text { Inventory Turnover }}$

$>$ Inventory Turnover $=\frac{\text { Harga Pokok Penjualan }}{\text { Persediaan Rata-rata }}$

- Days Receivable $=\frac{365}{\text { Account Receivable Turn Over }}$

Account Receivable Turn Over $=\frac{\text { Penjualan }}{\text { Piutang Usaha Rata-rata }}$

- Days Payable $=\frac{365}{\text { Account Payable Turnover }}$

Account Payable Turnover $=\frac{\text { Harga pokok penjualan }}{\text { Hutang Usaha Rata-rata }}$

e. Net Working Capital $\left(\mathrm{X}_{4}\right)$

Net working capital merupakan total aset lancar dikurangi total liabilitas lancar. Mengacu pada penelitian William dan Fauzi (2013), ukuran yang digunakan untuk menghitung Net working capital adalah sebagai berikut :

Net Working Capital $=\frac{\text { Aktiva Lancar-Hutang lancar }}{\text { Total Aset }} \times 100 \%$

\section{Pengujian Hipotesis}

Metode analisis yang digunakan pada penelitian ini adalah Analisis Regresi Linear Berganda. Persamaan regresi yang dibangun adalah:

$$
Y=a+b_{1} X_{1}+b_{2} X_{2}+b_{3} X_{3}+b_{4} X_{4}+e
$$

Di mana :

$$
\begin{aligned}
& \text { Y }=\text { Cash Holding } \\
& \text { a }=\text { Konstanta } \\
& \text { b1, b2,b3,b4, =Koefisien Regresi } \\
& \mathbf{X}_{\mathbf{1}} \quad=\text { Profitability } \\
& \mathbf{X}_{2} \quad=\text { Leverage } \\
& \mathbf{X}_{\mathbf{3}}=\text { Cash Conversion Cycle } \\
& \mathbf{X}_{\mathbf{4}} \quad=\text { Net Working Capital } \\
& \text { e } \quad=\text { Error Term }
\end{aligned}
$$

Sebelum dilakukanan alisis regresi linear berganda, terlebih dahulu akan dilakukan uji asumsi klasik. 


\section{HASIL PENELITIAN DAN PEMBAHASAN \\ 1. Gambaran Umum Sampel Penelitian}

Data pada penelitian ini merupakan data sekunder yang diperoleh dengan mengakses situs Bursa Efek Indonesia (BEI) untuk memperoleh laporan keuangan. Populasi penelitian ini adalah Perusahaan Manufaktur sektor Makanan dan Minuman yang listing di Bursa Efek Indonesia tahun 2014-2017. Pengambilan sampel dilakukan dengan menggunakan tehnik pengambilan sampel purposive sampling. Namun beberapa dari populasi tersebut akan dikeluarkan dari penelitian karena tidak memenuhi data yang dibutuhkan. Jumlah sampel penelitian adalah 15 perusahaan yang memenuhi kelengkapan dan kriteria data penelitian.

\section{Statistik Deskriptif}

Statistik deskriptif untuk keseluruhan data pengamatan dapat dirangkum dalam Tabel 5 berikut ini.

\section{Tabel 5 Statistik Deskriptif}

Descriptive Statistic

\begin{tabular}{|l|r|r|r|r|r|}
\hline & $\mathrm{N}$ & Minimum & Maximum & \multicolumn{1}{c|}{ Mean } & Std. Deviation \\
\hline Cash Hoding (Y) & 60 &, 0020 &, 6310 &, 152467 &, 1474554 \\
Profitabiity (X1) & 60 &,- 1110 &, 5820 &, 096767 &, 1188874 \\
Leverage (X2) & 60 &, 146 &, 752 &, 47172 &, 139250 \\
Cash Conversion Cycle (X3) & 60 & $-18,739$ & 521,150 & 109,72200 & 101,335462 \\
Net Working Capital (X4) & 60 &,- 986 &, 754 &, 00720 &, 343174 \\
Valid N (listwise) & 60 & & & & \\
\hline
\end{tabular}

Sumber: Hasil output SPSS 18 (data diolah)

Berdasarkan tabel 5 ditemukan beberapa hal sebagai berikut :

a) Nilai rata-rata Y (cash holding)yaitu 0,152467dengan standar deviasi sebesar 0,1474554. Nilai maksimumcash holdingsebesar 0,6310 dimiliki oleh PT. Delta Djakarta Tbkpada tahun 2017 dan nilai minimum cash holdingsebesar 0,002 dimiliki oleh PT. Tri Banyan Tirta Tbk pada tahun 2015. Menurut Brigham dan Houston (2006), rata-rata perusahaan manufaktur memiliki jumlah kas sebesar 1,5\% dari total aktiva. Artinya, PT. Delta Djakarta Tbk memiliki likuiditas yang tinggi karena memiliki nilai cash holding yang tinggi pada tahun 2017. Namun demikian, memiliki likuiditas yang tinggi tidak menyatakan bahwa perusahaan tersebut baik, sebab memiliki kas yang banyak berakibat pada pemanfaatan kas yang kurang efisien karena kas tersebut menganggur dan tidak menghasilkan keuntungan. Sedangkan PT. Tri Banyan Tirta Tbk pada tahun 2015 memiliki likuiditas yang rendah 
karena nilai cash holding yang terlalu rendah. Nilai cash holdingyang terlalu rendah akan menyulitkan perusahaan dalam membiayai kegiatan operasionalnya.

b) Nilai rata-rata $X_{1}$ (profitability) yaitu 0,096767dengan standar deviasi sebesar 0,1188874. Nilai maksimum profitabilitysebesar 0,5820 dimiliki oleh PT.Multi Bintang Indonesia Tbkpada tahun 2016 dan nilai minimum sebesar -0,1110 dimiliki oleh PT. Tiga Pilar Sejahtera Food Tbk pada tahun 2017. Artinya, pada tahun 2016 PT. Multi Bintang IndonesiaTbk memiliki profitabilityyang sangat tinggi. Namun pada tahun 2017 justru sebaliknya PT. Tiga Pilar Sejahtera Food Tbk memiliki profitabilityyang menurun.

c) Nilai rata-rata $\mathrm{X}_{2}$ (leverage) yaitu 0,47172dengan standar deviasi sebesar 0,139250. Nilai leverage maksimum sebesar 0,752 dimiliki oleh PT.Multi Bintang Indonesia Tbkpada tahun 2014 dan nilai minimum sebesar 0,146dimiliki oleh PT. Delta Djakarta Tbk pada tahun 2017. Artinya, pada tahun 2014 PT. Multi Bintang Indonesia Tbk memilikileverageyang sangat tinggi. Namun pada tahun 2017 justru sebaliknya PT.Delta Djakarta Tbk memiliki leverageyang menurun.

d) Nilai rata-rata $\mathrm{X}_{3}$ (cash conversion cycle) yaitu 109,72200 dengan standar deviasi sebesar 101,335462. Nilai cash conversion cycle maksimum sebesar 521,150 dimiliki oleh PT. Delta Djakarta Tbk pada tahun 2017 dan nilai minimum sebesar -18,739 dimiliki oleh PT. Nippon Indosari Corporindo Tbk pada tahun 2015. Artinya, pada tahun 2017 PT. Delta Djakarta Tbkmemiliki siklus konversi kas yang cukup lama, sedangkan pada tahun 2015 PT. Nippon Indosari Corporindo Tbk memiliki siklus konversi kas yang sangat cepat.

e) Nilai rata-rata rata-rata $\mathrm{X}_{4}$ (net working capital) yaitu 0,00720dengan standar deviasi sebesar 0,343174. Nilai maksimum net working capitalsebesar 0,754dimiliki oleh PT. Delta Djakarta Tbk pada tahun 2017 dan nilai minimum sebesar-0,986dimiliki oleh PT. Indofood Sukses Makmur Tbk pada tahun 2017. Artinya, pada tahun 2017 PT. Delta Djakarta Tbkmemiliki net working capitalyang tinggi, sedangkan pada tahun 2017 PT. Indofood Sukses Makmur Tbk memilikinet working capital yang menurun.

\section{Uji Asumsi Klasik}

Data penelitian telah memenuhi kriteria uji asumsi klasik dengan uji normalitas data, uji atokorelasi, uji heteroskedastisitas, dan uji multikolinieritas. Hasil uji asumsi klasik menunjukkan bahwa data 
terdistribusi normal, bebas autokorelasi, heteroskedastisitas dan multikolinieritas (terlampir). Selanjutnya dapat dilakukan uji hipotesis melalui Analisis Regresi Linier Berganda.

\section{Persamaan Regresi Linier Berganda}

Tabel 6 Hasil Persamaan Regresi Linier Berganda Coefficients $^{\mathrm{a}}$

\begin{tabular}{|ll|r|r|r|r|r|}
\hline \multirow{2}{*}{ Model } & \multicolumn{2}{|c|}{$\begin{array}{c}\text { Unstandardized } \\
\text { Coefficients }\end{array}$} & $\begin{array}{c}\text { Standardized } \\
\text { Coefficients }\end{array}$ & & \\
\cline { 2 - 4 } & \multicolumn{1}{|c|}{$\mathrm{B}$} & Std. Error & \multicolumn{1}{|c|}{ Beta } & \multicolumn{1}{c|}{ T } & \multicolumn{1}{c|}{ Sig. } \\
\hline 1 & (Constant) &, 207 &, 079 & & 2,624 &, 011 \\
& Profitabiity &, 459 &, 123 &, 370 & 3,727 &, 000 \\
& Leverage &,- 335 &, 155 &,- 316 & $-2,159$ &, 035 \\
Cash Conversion Cycle &, 001 &, 000 &, 369 & 3,536 &, 001 \\
& Net Working Capital &,- 005 &, 064 &,- 012 &,- 082 &, 935 \\
\hline
\end{tabular}

a. Dependent Variable: Cash Hoding

Sumber :Hasil Output SPSS 18 (data diolah)

Analisis linier berganda menemukan persamaan regresi penelitian ini, yaitu :

$Y=0,207+0,459 X_{1}-0,335 X_{2}+0,001 X_{3}-0,005 X_{4}+e$

Di mana :

\begin{tabular}{|c|c|}
\hline $\mathbf{Y}$ & $=$ Cash Holding \\
\hline & $=$ Konstanta \\
\hline 1, b2,b3,b4, & $=$ Koefisien regresi \\
\hline & $=$ Profitability \\
\hline 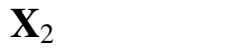 & $=$ Leverage \\
\hline 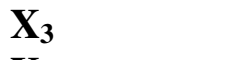 & $=$ Cash Conversion Cycle \\
\hline & $\begin{array}{l}=\text { Net } \text { Working Capital } \\
=\text { Error Term }\end{array}$ \\
\hline
\end{tabular}

Hasil persamaan regresi ini dapat dijelaskan sebagai berikut:

a. Nilai konstanta sebesar 0,207 artinya jika variabel profitability, leverage,cash conversion cycle dan net working capitalbernilai 0 maka cash holding akannaik sebesar 0,207.

b. Nilai koefisien profitabilitysebesar 0,459,artinya setiap kenaikan profitability $1 \%$ akan meningkatkan cash holding sebesar 0,459. 
c. Nilai koefisien leverage sebesar -0,335, artinya setiap kenaikan leverage $1 \%$ akan menurunkan cash holding sebesar 0,335 .

d. Nilai koefisien cash conversion cycle 0,001 artinya setiap kenaikan cash conversion cycleselama 1 hari akan meningkatkan cash holding sebesar 0,001 .

e. Nilai koefisien net working capitalsebesar-0,005 artinya kenaikan net working capital $1 \%$ akan menurunkan cash holding sebesar 0,005 .

\section{Koefisien Determinasi $\left(\mathbf{R}^{2}\right)$}

Tabel 7 Hasil Uji Koefisien Determinasi $\left(\mathbf{R}^{2}\right)$

Model Summary

\begin{tabular}{|r|l|r|l|l|}
\hline Model & R & R Square & $\begin{array}{l}\text { Adjusted R } \\
\text { Square }\end{array}$ & $\begin{array}{l}\text { Std. Error of the } \\
\text { Estimate }\end{array}$ \\
\hline $\mathbf{1}$ &, $681^{\mathrm{a}}$ &, 464 &, 425 &, 1117738 \\
\hline
\end{tabular}

Berdasarkan Tabel 7 diperoleh nilai koefisien korelasi $\left(\mathrm{R}^{2}\right)$ sebesar 0,464 atau 46,4\%. Artinya, variabel independen (profitability, leverage, cash conversion cycledan net working capital) mempunyai pengaruh terhadap cash holding pada perusahaan manufaktur kelompok Makanan dan Minuman yang terdaftar di Bursa Efek Indonesia sebesar 46,4\% sedangkan sisanya $53,6 \%$ dipengaruhi oleh variabel lain yang tidak terungkap atau tidak diteliti dalam penelitian ini.

\section{Uji Signifikasi Simultan (Uji F)}

Uji statistik $F$ berguna untuk menunjukkan apakah semua variabel independen yang dimasukkan dalam model mempunyai pengaruh secara bersama- sama terhadap variabel dependen (Ghozali,2006).

\section{Tabel 8 Hasil Uji Signifikasi Simultan (Uji F)}

ANOVA ${ }^{b}$

\begin{tabular}{|ll|r|r|r|r|c|}
\hline \multicolumn{1}{|l|}{ Model } & \multicolumn{1}{|c|}{$\begin{array}{c}\text { Sum of } \\
\text { Squares }\end{array}$} & \multicolumn{1}{c|}{ Df } & \multicolumn{1}{c|}{$\begin{array}{c}\text { Sean } \\
\text { Square }\end{array}$} & \multicolumn{1}{c|}{ F } & \multicolumn{1}{c|}{ Sig. } \\
\hline 1 & Regression &, 596 & 4 &, 149 & 11,920 &, $000^{\mathrm{a}}$ \\
& Residual &, 687 & 55 &, 012 & & \\
& Total & 1,283 & 59 & & & \\
\hline
\end{tabular}

a. Predictors: (Constant), Net Working Capital, Profitabiity, Cash

Conversion Cycle, Leverage

b. Dependent Variable: Cash Hoding

Sumber :Hasil Output SPSS 18 (data diolah) 
Tabel 8 di atas menyatakan bahwa nilai Fhitung sebesar 11,920dengan signifikansi 0,000 dan nilai $F$ tabel sebesar 2,769dengan signifikansi 0,05 (11,920> 2,769). Karena Fhitung > Ftabel dan sig F < 0,05 maka $\mathrm{H}_{0}$ ditolak dan $\mathrm{H}_{5}$ diterima. Dengan demikian, profitability, leverage, cash conversion cycledannet working capitalsecara simultan berpengaruh signifikan terhadap Cash Holding.

\section{Uji Signifikansi Parsial (Uji t)}

Uji statistik $\mathrm{t}$ menunjukkan seberapa jauh pengaruh satu variabel independen secara individual dalam menerangkan variasi variabel dependen (Ghozali, 2006).

Tabel 9 Hasil Uji Signifikansi Parsial (Uji t) Coefficients $^{\mathrm{a}}$

\begin{tabular}{|c|c|c|c|c|c|c|}
\hline \multirow{2}{*}{\multicolumn{2}{|c|}{ Model }} & \multicolumn{2}{|c|}{$\begin{array}{c}\text { Unstandardized } \\
\text { Coefficients }\end{array}$} & \multirow{2}{*}{$\begin{array}{c}\text { Standardized } \\
\text { Coefficients }\end{array}$} & \multirow[b]{2}{*}{$\mathrm{T}$} & \multirow[b]{2}{*}{ Sig. } \\
\hline & & $\mathrm{B}$ & Std. Error & & & \\
\hline & (Constant) & ,207 & ,079 & & 2,624 &, 011 \\
\hline & Profitabiity & ,459 &, 123 &, 370 & 3,727 & ,000 \\
\hline & Leverage &,- 335 &, 155 &,- 316 & $-2,159$ & 035 \\
\hline & Cash Conversion Cycle &, 001 &, 000 &, 369 & 3,536 & ,001 \\
\hline & Net Working Capital &,- 005 &, 064 &,- 012 &,- 082 & ,935 \\
\hline
\end{tabular}

a. Dependent Variable: Cash Hoding

Sumber :Hasil Output SPSS 18 (data diolah)

Berdasarkan tabel 9 dapat dijelaskan beberapa hal berikut :

a) Profitability $\left(\mathrm{X}_{1}\right)$ memiliki nilai t-hitung sebesar 3,727, sedangkan nilai t-tabel sebesar 2,004. Karena t-hitung $(3,727)>$ t-tabel $(2,004)$ dan signifikansi $(0,000)<0,05$ maka $\mathrm{H}_{0}$ ditolak dan $\mathrm{H}_{1}$ diterima. Dengan demikian, dapat disimpulkan bahwa profitabilityberpengaruhpositif signifikan terhadap cash holding.

b) Leverage $\left(\mathrm{X}_{2}\right)$ memiliki nilai t-hitung sebesar $-2,159$, sedangkan nilai t-tabel sebesar 2,003. Karena t-hitung $(-2,159)<\mathrm{t}$-tabel $(2,004)$ dan signifikansi $(0,035)<0,05$ maka $\mathrm{H}_{0}$ ditolak dan $\mathrm{H}_{2}$ diterima. Dengan demikian, dapat disimpulkan bahwa leverageberpengaruh negatif signifikan terhadap cash holding.

c) Cash conversion cycle $\left(\mathrm{X}_{3}\right)$ memiliki nilai t-hitung sebesar 3,536, sedangkan nilai t-tabel sebesar2,004. Karena t-hitung $(3,536)>\mathrm{t}$ - 
tabel $(2,004)$ dan signifikansi $(0,001)<0,05$ maka $\mathrm{H}_{0}$ ditolak dan $\mathrm{H}_{3}$ diterima. Dengan demikian, dapat disimpulkan bahwa cash conversion cycleberpengaruh positif secara signifikan terhadap cash holding.

d) Net working capital $\left(\mathrm{X}_{4}\right)$ memiliki nilai t-hitung sebesar -0,082, sedangkan nilai t-tabel sebesar 2,004. Karena t-hitung $(-0,082)<\mathrm{t}-$ tabel $(2,004)$ dan signifikansi $(0,935)>0,05$ maka $\mathrm{H}_{0}$ diterima dan $\mathrm{H}_{4}$ ditolak. Dengan demikian, dapat disimpulkan bahwa net working capital berpengaruh negatif tidak signifikan terhadap cash holding.

\section{Pengaruh Profitability terhadap Cash Holding}

Menurut Gitman dan Zutter (2015) mendefinisikan profitability sebagai hubungan antara pendapatan dan biaya yang dihasilkan dari penggunaan aset perusahaan baik aset lancar maupun aset tetap.Dari Tabel 9 ditemukan bahwa $\mathrm{H}_{0}$ ditolak dan $\mathrm{H}_{1}$ diterima. Dengan demikian, dapat disimpulkan bahwa profitabilityberpengaruhpositif signifikan terhadap Cash Holding.Hal ini sesuai dengan pecking order theory yang menyatakan bahwa perusahaan lebih memilih menggunakan laba ditahan sebagai tambahan modal dibandingkan mendapatkannya melalui penerbitan ekuitas yang tergolong mahal. Yeboah dan Agyei dalam Silaen (2017) menjelaskan bahwa perusahaan dengan tingkat profitability yang tinggi akan menyebabkan perusahaan memegang jumlah kas yang besar pula. Yang artinya semakin besar kemampuan perusahaan dalam menghasilkan laba, maka semakin besar pula jumlah kas perusahaan yang dimiliki.Hasil penelitian ini mendukung hasil penelitian Simanjuntak danWahyuni (2017) yang menyatakan bahwa profitability berpengaruh positif terhadap cash holding.

\section{Pengaruh Leverage terhadap Cash Holding}

Menurut Ali et al. (2016) dalam Simanjuntak dan Wahyuni (2017) menyatakan bahwa leveragemerupakan kondisi dimana perusahaan membeli asetnya secara kredit dengan kepercayaan bahwa laba dari aset tersebut akan lebih jika dibandingkan melakukan pimjaman. Tabel 9 memberikan informasi bahwaH bitolak dan menerimaH $_{2}$. Dengan demikian, dapat disimpulkan bahwa leverage berpengaruh negatif secara signifikan terhadap cash holding.

Berdasarkan trade-off theory, perusahaan dengan leverage yang tinggi akan berusaha untuk meminimalkan biaya kas dengan pendanaan eksternal. Leverage yang tinggi menunjukkan kemampuan rasio 
perusahaan untuk menerbitkan hutang sehingga perusahaan dapat menggunakan pinjaman sebagai pengganti cash holding. Ferreira dan Vilela (2004) menemukan bahwa perusahaan dengan tingkat leverage yang lebih tinggi memiliki kemampuan untuk mendapatkan pendanaan eksternal lebih mudah dan murah sehingga memungkinkan perusahaan untuk mengurangi jumlah kas yang dipegang. Penelitian yang dilakukan oleh William dan Fauzi (2004) juga menemukan bahwa perusahaan dengan rasio utang yang lebih tinggi memiliki posisi kas yang lebih rendah.Hasil penelitian ini mendukung hasil penelitian Simanjuntak dan Wahyuni (2017) yang menyatakan bahwa leverageberpengaruh negatif terhadap cash holding.

\section{Pengaruh Cash Conversion Cycle terhadap Cash Holding}

Menurut Syarief dan Wilujeng (2009)cash conversion cycledi defenisikan sebagai waktu dalam satuan hari yang diperlukan untuk mendapatkan kas dari penagihan piutang ditambah penjualan persediaan dikurangi dengan pembayaran utang. Siklus konversi kas menunjukkan seberapa cepat perusahaan menghasilkan produknya, dari membayar biaya persediaan hingga mengumpulkan kas dari konsumen dalam bentuk pembayaran atas produk jadi. Semakin lama siklus ini terjadi, semakin besar kebutuhan pendanaan internal perusahaan untuk membayar kebutuhan bahan baku perusahaan.

Tabel 9 memberikan informasi bahwa $\mathrm{H}_{0}$ ditolak dan menerima $\mathrm{H}_{3}$ diterima. Dengan demikian, dapat disimpulkan bahwa cash conversion cycleberpengaruh positif secara signifikan terhadap cash holding.Hasil penelitian ini sejalan dengan pecking order theory bahwa semakin lama siklus konversi kas maka semakinbesar juga kebutuhanpendanaaninternal sehingga perusahaan cenderung menahan kas dalam jumlah besar.Hasil penelitian ini juga didukung oleh penelitian William danFauzi (2013) yang menyatakan bahwa cash conversion cycleberpengaruh positif terhadap cash holding.

\section{Pengaruh Net Working Capitalterhadap Cash Holding}

Menurut Ross (2015) menyatakan bahwa net working capital merupakan aset lancar dan kewajiban lancar yang dapat menghasilkan modal kerja yang positif saat aset lancar lebih besar dari kewajiban lancar. Tabel 9 memberikan informasi bahwa $\mathrm{H}_{0}$ diterima dan $\mathrm{H}_{4}$ ditolak. Dengan demikian, dapat disimpulkan bahwa networking capital berpengaruh negatif tidak signifikan terhadap cash holding. Hasil penelitian ini sejalan 
dengan trade-off theoryyang menyatakan terdapat hubungan negatif antara modal kerja bersih dan cash holding.

Bates et al. (2009) menyatakan bahwa modal kerja bersih dapat dipakai sebagai substitusi kas perusahaan. Hal ini dikarenakan kemudahan dalam merubah bentuknya ke dalam bentuk kas ketika sewaktu-waktu perusahaan memerlukannya. Jadi, meningkatnya modal kerja bersih yang dimiliki perusahaan mengakibatkan menurunnya tingkat cash holding. Modal kerja bersih merupakan pengganti uang tunai karena pada saat dibutuhkan, modal kerja bersih dapat dengan cepat dilikuidasi untuk pendanaan (Ferriera dan Vilela (2004). Sehingga, perusahaan dengan modal kerja yang banyak cenderung memegang kas dalam jumlah yang sedikit. Penelitian yang dilakukan oleh Bates (2009), Ferreira dan Vilela (2004), Prasentianto (2014), dan Afza dan Adnan (2007) menemukan adanya hubungan negatif antara net working capital dengan cash holding.

\section{KESIMPULAN DAN SARAN}

\section{Kesimpulan}

Berdasarkan hasil penelitian dan, maka diperoleh kesimpulan sebagai berikut:

a. Variabel profitability berpengaruh positif secara signifikanterhadap cash holding.

b. Variabel leverageberpengaruh negatif secara signifikan terhadap cash holding

c. Variabel cash conversion cycle berpengaruh positif secara signifikan terhadap cash holding.

d. Varabel net working capital berpengaruh negatif tidak signifikan terhadap cash holding.

\section{Keterbatasan dan Saran}

Berdasarkan kesimpulan di atas maka penulis memberikan saran sebagai berikut :

a. Peneliti selanjutnya diharapkan dapat mengembangkan penelitian ini denganmenambahkanvariabel lain-lain yang kemungkinan mempengaruhi tingkat cash holding.

b. Para praktisi khususnya manajer perusahaan diharapkan agar mempertimbangkan faktor-faktor yang mempengaruhi kebijakan cash holding hasil dari penelitian ini. Namun, para praktisi juga diharapkan tidak hanya terpaku pada hasil penelitian ini dalam menentukan kebijakan cash holding. Sebab terdapat faktor-faktor lain yang perlu dipertimbangkan dalam menentukan kebijakan cash holding. 


\section{DAFTAR PUSTAKA}

Afza, T., dan Adnan, S.M. 2007. Determinants of Corporate Cash Holdings: A Case Study of Pakistan. Proceedings of Singapore Economic Review Confrence (SERC), Aug 01-04, 1-12

Bates et al. 2009. "Analisis faktor-faktor yang mempengaruhi Kebijakan cash holding pada perusahaan manufaktur yang Listing di bursa efek Indonesia tahun 2010-2014'. Diponegoro Journal of Management Vol. 5, No. 4

Brigham, E.F. dan Houston, J.F. 2006. Manajemen Keuangan, Edisi Kedelapan. Jakarta: Erlangga.

Ferreira, Miguel and Vilela, Antonio. 2004. Why Do Firm Hold Cash? Evidence from EMU Countries. European Financial Management, Vol.10 No. 2 295-319.

Gitman, Lawrence J. and Chad J. Zutter. 2015. Principle Of Managerial Finance, Fourteenth Edition. Singapore: Pearson Education

Ikatan Akuntansi Indonesia (IAI). 2009. Pernyataan Standar Akuntansi Keuangan (PSAK) No.2. Jakarta: Penerbit Salemba Empat.

Fahmi, Irham. 2014. Manajemen Keuangan Perusahaan dan Pasar Modal, Edisi Pertama. Jakarta : Mitra Wacana Media.

Jensen, M.C., \& Meckling, W.H. 1976. Theory of the Firm: Managerial Behavior, Agency Costs and Ownership Structure. Journal of Financial Economics,3 (4), 305-360.

Kasmir. 2011. Analisis laporan Keuangan. Jakarta: Lembaga Penerbit Rajagrafindo Persada

Hanafi, Mamduh M. dan A. Halim. 2014. Analisis Laporan Keuangan.,Edisi Tujuh.,UPP AMP YKPN, Yogyakarta.

Marfuah dan ArdanZulhilmi. 2014. Pengaruh Profitability, Leverage, Net Working Capital, Cash Conversion Cycle dan Leverage Terhadap Cash Holding Perusahaan. Jurnal Universitas Islam Indonesia.

Megginson, W.L. \& Wei, Z. 2010. Determinants And Value of Cash Holdings: Evidence From China's Privatized Firms. SSRN Working Paper Series : 1-37

Modigliani, F., \& Miller, M.H. (1963). Corporate Income Taxes and the Cost of Capital: A Correction. The American Economic Review, 53 (3), 433-443.

Myers, S.C., \& Majluf, N.S. 1984. Corporate Financing and Investment Decisions when Firms Have Information that Investors Do Not Have. Journal of Financial Economics13, 187-221 
Prasentian, Hanafi. 2014. " Analisis faktor-faktor yang mempengaruhi tingkat cash holding ( studi empiris pada perusahaan Property dan real Estate yang terdaftar di bursa efek indonesia tahun 20092013)". Skripsi, Fakultas Ekonomika dan Bisnis Universitas Diponegoro, 2014

Silaen, Reni. 2017. Analisis Faktor-Faktor yang Mempengaruhi Tingkat Cash Holding pada Bank Umum yang Terdaftar di Bursa Efek Indonesia Tahun 2011-2015. Skripsi, Fakultas Ekonomika dan Bisnis Universitas Diponegoro

Simanjuntak, Saul F. dan A. S. Wahyuni. 2017. Faktor-Faktor yangMempengaruhi Cash Holding Perusahaan. Jurnal bisnis dan Akuntansi. Vol19, No 1a. 25-31

Ross, Stephen A. 2015. Pengantar Keuangan Perusahaan. Jakarta: Penerbit Salemba Empat

Syarief, M. Ednan, dan I. P.Wilujeng.2009. Cash Conversion Cycle dan Hubungannya dengan Ukuran Perusahaan, Profitabilitas, dan Manajemen Modal Kerja. Jurnal Ekonomi dan Bisnis, Tahun 14 No 1

Utami, Rachmawati B. dan Prasetiono. 2016. Analaisis Pengaruh TATO, WCTO, dan DER Terhadap Nilai Perusahaan dengan ROA Sebagai Variabel Intervening. Diponegoro Journal of Management Vol. 5 No.2

Webston dan Copeland. 1996. Financial Theory and Corporate Policy. Weslet Addison.

Wijaya, A.L., Bandi, dan S. Hartoko. 2010. Pengaruh Kualitas Akrualdan Leverage Terhadap Cash Holding Perusahaan. Jurnal Akuntansi dan Keuangan. Vol.7 No 2.

William dan S. Fauzi. 2013. Analisis Pengaruh Profitabiity, Leverage, Net Working Capital, dan Cash Conversion Cycle terhadap Cash Holdings Perusahaan Sektor Pertambangan. Jurnal Ekonomi dan Keuangan. Vol1, No.2. 